Halimatussa'idah, et al/Jurnal Ekonomi Syariah Teori dan Terapan Vol. 6 No. 7 Juli 2019: 1348-1364; ANALISIS FAKTOR - FAKTOR YANG MEMPENGARUHI TINGKAT BAGI HASIL TABUNGAN DEPOSITO MUDHARABAH PADA PERBANKAN SYARIAH DI INDONESIA PERIODE 2012 -2016

\title{
ANALISIS FAKTOR - FAKTOR YANG MEMPENGARUHI TINGKAT BAGI HASIL TABUNGAN DEPOSITO MUDHARABAH PADA PERBANKAN SYARIAHDI INDONESIA PERIODE 2012 -20161
}

\author{
Halimatussa'idah \\ Departemen Ekonomi Syariah-Fakultas Ekonomi dan Bisnis-Universitas Airlangga \\ Email: halimatus846@gmail.com \\ Dina Fitrisia Septiarini \\ Departemen Ekonomi Syariah-Fakultas Ekonomi dan Bisnis-Universitas Airlangga \\ Email: dinafitrisia@feb.unair.ac.id
}

\begin{abstract}
:
The purpose of this research is to analyze the effect of Non Performing Financing, Operational Efficiency Ratio, BI Rate and inflation toward the rate of return mudharabah deposits islamic bank industries in Indonesia start from January 2012 until December 2016. This research use quantitative approach. The analysis method used in this research is time series regression using eviews 9.0 program. This research used saturation sampling. Sample that used in this research were taken from Islamic Bank Statistic issued by OJK, while BI Rate and Inflation taken from www.bi.go.id. The result show that Non Performing Financinghas no effect on the rate of return mudharabah deposits, Beban Operasional Pendapatan Operasional has no effect on the rate of return mudharabah deposits. While BI Rate has positive and significant on the rate of return mudharabah deposits, and than variabel inflation has negative and significant on the rate of return mudharabah deposits. All of the independent variables in this research are simultaniosly significant on the rate of return mudharabah deposits.
\end{abstract}

Keywords: Non Performing Financing(NPF), Operational Efficiency Ratio (BOPO), BI Rate, inflation, the rate of return mudharabah deposits.

I.

\section{PENDAHULUAN}

Perbankan syariah adalah suatu sistem perbankan yang menjadikan Islam sebagai landasan utama dalam menjalankan segala transaksinya.Oleh karena itu, bank syariah tidak menggunakan sistem bunga yang dilarang oleh Islam melainkan menggunakan prinsip bagi hasil.Islam telah mengatur segala aspek kehidupan manusia, terutama masalah perekonomian yang merupakan roda penggerak kesejahteraan umat.Salah satunya adalah mengenai menabung atau investasi.Bank syariah memiliki fungsi financial Intermediaries yakni menghimpun dana dari masyarakat dan menyalurkannya sebagai pembiayaan. Salah satu bentuk penghimpunannya adalah deposito berjangka, dengan memberikan tingkat bagi hasil yang menarik sehingga dapat meningkatkan minat masyarakat untuk menginvestasikan dananya di bank syariah. Dalam hal ini, semakin besar laba yang diperoleh bank syariah, maka akan semakin tinggi pula bagi hasil yang akan dibagikan kepada nasabah.

Berdasarkan

Laporan Perkembangan Keuangan Syariah (LPKS) tahun 2016, market share bank syariah per-Desember 2016 mencapai angka

\footnotetext{
${ }^{1}$ Jurnal ini merupakan bagian dari skripsi Halimatussa'idah, NIM: 041411431017 , yang diuji pada tanggal 19 Januari 2018.
} 
Halimatussa'idah, et al/Jurnal Ekonomi Syariah Teori dan Terapan Vol. 6 No. 7 Juli 2019: 1348-1364; ANALISIS FAKTOR - FAKTOR YANG MEMPENGARUHI TINGKAT BAGI HASIL TABUNGAN DEPOSITO MUDHARABAH PADA PERBANKAN SYARIAH DI INDONESIA PERIODE 2012 -2016

$5.33 \%$ atau meningkat sebesar $0,46 \%$ dari 4.87\% pada tahun 2015. Karim (2005), membagi segmentasi perbankan syariah menajdi tiga bagian, yaitu syariah loyalist, floating market dan conventional loyalist.Sasaran utama target pasar bank syariah adalah floating market. Floating market adalah konsumen yang mengutamakan benefit seperti kepraktisan transaksi serta kemudahan akses.Biasanya disegmen ini, pengguna memperhatikan kemanfaatan dan variasi produk syariah dan juga melihat tinggi rendahnya bagi hasil yang dibagikan kepada nasabah sehingga mereka mau menggunakannya.Floating market menjadi target pasar utama bank syariah, maka dari itu bank syariah harus mampu bersaing dengan bank konvensional agar mereka mau menempatkan dananya pada bank syariah.

Perbankan Syariah dalam menentukan tingkat bagi hasil yang akan dibagikan tentunya memperhatikan faktor internal dan eksternal. Beberapa hal diatas menjadikan perlunya dilakukan penelitian pada faktor - faktor internal yakni Non Performing Financing(NPF) dan Biaya Operasional Pendapatan Operasional (BOPO), maupun dari faktor eksternal yaitu BI Rate dan inflasi yang dapat mempengaruhi bank syariah dalam menentukan tingkat bagi hasil deposito mudharabah yang akan dibagikan kepada nasabah.

\section{Rumusan Masalah}

Rumusan masalah dalam penelitian ini adalah apakah terdapat pengaruh signifikan Non Performing Financing, Beban Operasional Pendapatan Operasional, BI Rate dan inflasi secara simultan terhadap tingkat bagi hasil deposito mudharabah dan apakah terdapat pengaruh signifikan Non Performing Financing, Beban Operasional Pendapatan Operasional, BI Rate dan inflasi secara parsial terhadap tingkat bagi hasil deposito mudharabah.

\section{Tujuan Penelitian}

Tujuan penelitian ini adalah untuk menguji dan menganalisis signifikansi pengaruh Non Performing Financing (NPF), Beban Operasional Pendapatan Operasional (BOPO), BI Rate dan inflasi secara simultan maupun parsial terhadap tingkat bagi hasil deposito mudharabah.

\section{LANDASAN TEORI}

\section{Perbankan Syariah}

Pada umumnya yang dimaksud bank syariah adalah lembaga keuangan yang usaha pokoknya memberikan kredit dan jasa - jasa lain dalam lalu lintas pembayaran serta peredaran vang yang beroperasi disesuaikan dengan prinsip syariah.

\section{Deposito Mudharabah}

\section{Pengertian Deposito Mudharabah}

Pengertian deposito menurut Undang - Undang Nomor 21 Tahun 2008 adalah investasi dana berdasarkan akad mudharabah atau akad lain yang tidak bertentangan dengan prinsip syariah yang penarikannya hanya dapat 
Halimatussa'idah, et al/Jurnal Ekonomi Syariah Teori dan Terapan Vol. 6 No. 7 Juli 2019: 1348-1364; ANALISIS FAKTOR - FAKTOR YANG MEMPENGARUHI TINGKAT BAGI HASIL TABUNGAN DEPOSITO MUDHARABAH PADA PERBANKAN SYARIAH DI INDONESIA PERIODE 2012 -2016

dilakukan pada waktu tertentu berdasarkan akad antara nasabah penyimpan dan bank syariah dan/atau UUS. Baik bank syariah mau konvensional, tabungan deposito memiliki jangka waktu 1 bulan, 3 bulan, 6 bulan dan 12 bulan.

\section{Landasan Hukum Deposito Mudharabah}

Pada bank syariah, sama halnya dengan tabungan, deposito berjangka menggunakan akad mudharabah. Hal tersebut telah diatur dalam peraturan DSN MUI mengenai deposito syariah, yakni fatwa : 03/DSN-MUI/IV/2000 bahwa deposito syariah yang dibenarkan adalah menggunakan prinsip mudharabah.

\section{Macam - Macam Deposito Mudharabah}

Menurut Karim (2014: 364), produk deposito mudharabah dibagi menjadi dua bentuk, yakni mudharabah muthlaqah dan mudharabah muqayyadah.

a. Mudharabah Muthlaqah (Unrestricted Investment Account, URIA)

Mudharabah Mutlaqah atau yang biasa disebut investasi umum adalah suatu produk investasi ketika nasabah (shahibul mal) tidak memberikan batas terhadap bank syariah menginvestasikan dananya.

b. Mudharabah muqayyadah (Restricted Investment Account, RIA)

Mudharabah Muqayyadah atau investasi khusus adalah pihak nasabah atau shahibul maal memberikan batasan - batas terhadap dana yang akan diinvestasikan oleh bank syariah.

Non Performing Financing (NPF)
Non performing Financing (NPF) merupakan istilah untuk rasio pembiaayaan bermasalah pada bank syariah.Sedangkan pada konvensional, pembiayaan bermasalah diukur menggunakan rasio Non Performing Loan (NPL). NPF adalah rasio yang menggambarkan besarnya pembiayaan bermasalah dengan total pembiayaan yang disalurkan oleh bank syariah.

Berdasarkan Lampiran Surat Edaran Bank Indonesia Nomor 9/24/DPbS Tahun 2007, rumus NPF adalah sebagai berikut :

$$
N P F=\frac{\text { pembiayaan }(K L, D, M)}{\text { total pembiayaan }} \times 100
$$

Tabel 1.

Kriteria Peringkat Non-Perfoming Financing (NPF)

\begin{tabular}{|c|c|}
\hline Kriteria Peringkat & Hasil NPF \\
\hline Peringkat 1 & $<2 \%$ \\
\hline Peringkat 2 & $2 \% \leq \mathrm{NPF}<5 \%$ \\
\hline Peringkat 3 & $5 \% \leq \mathrm{NPF}<8 \%$ \\
\hline Peringkat 4 & $8 \% \leq \mathrm{NPF}<12 \%$ \\
\hline Peringkat 5 & $\mathrm{NPF} \geq 12 \%$ \\
\hline
\end{tabular}

Sumber : Lampiran Surat Edaran Bank Indonesia Nomor 9/24/DPbS Tahun 2007.

Batasan NPF maupun NPL telah ditetapkan oleh Bnak Indonesia dalam peraturan Nomor 3/25/PBI/2001 yakni sebesar $5 \%$.

\section{Biaya Operasional Pendapatan} Operasional (BOPO)

Menururt k dan Sunaryo (2012), BOPO (Biaya Operasional Pendapatan Operasional) merupakan rasio efisiensi yang digunakan untuk mengukur kemampuan manajemen bank dalam 
Halimatussa'idah, et al/Jurnal Ekonomi Syariah Teori dan Terapan Vol. 6 No. 7 Juli 2019: 1348-1364; ANALISIS FAKTOR - FAKTOR YANG MEMPENGARUHI TINGKAT BAGI HASIL TABUNGAN DEPOSITO MUDHARABAH PADA PERBANKAN SYARIAH DI INDONESIA PERIODE 2012 -2016

mengendalikan biaya operasional terhadap pendapatan operasionalnya.

Berdasarkan Surat Edaran Bank Indonesia No.13/24/DPNP. 25 Oktober 2011 , rasio BOPO dapat dihitung dengan rumus sebagai berikut:

$$
\text { BOPO }=\frac{\text { biaya operasional }}{\text { pendapatan operasioanl }} \times 100 \%
$$

Tabel 2.

\section{Kriteria Peringkat Biaya Operasional}

Pendapatan Operasional (BOPO)

\begin{tabular}{|c|l|c|}
\hline Peringkat & \multicolumn{1}{|c|}{ Kriteria } & Keterangan \\
\hline Peringkat 1 & BOPO $\leq 83 \%$ & Sangat Baik \\
\hline Peringkat 2 & $\begin{array}{l}83 \%<\mathrm{BOPO} \leq \\
85 \%\end{array}$ & Baik \\
\hline Peringkat 3 & $\begin{array}{l}85 \%<\mathrm{BOPO} \\
\leq 87 \%\end{array}$ & Cukup Baik \\
\hline Peringkat 4 & $\begin{array}{l}87 \%<\mathrm{BOPO} \\
\leq 89 \%\end{array}$ & Kurang Baik \\
\hline Peringkat 5 & $\mathrm{BOPO}>89 \%$ & Lemah \\
\hline
\end{tabular}

Sumber : Surat Edaran Bank Indonesia

No.13/24/DPNP. 25 Oktober 2011

Tingkat suku bunga Bank Indonesia (BI Rate)

Menurut kamus Bank Indonesia, BI Rate merupakan suku bunga kebijakan yang mencerminkan sikap atau stance kebijakan moneter yang ditetapkan oleh Bank Indonesia yang diumumkan ke publik.BI Rate diumumkan oleh dewan gubernur Bank Indonesia setiap rapat dewan gubernur bulanan dan diimplementasikan pada operasi moneter yang dilakukan Bank Indonesia melalui pengelolaan likuiditas di pasar uang untuk mencapai sasaran operasional kebijakan moneter.
Inflasi

Menurut Latumeirissa (2012:22), definisi singkat dari inflasi adalah kecenderungan dari harga - harga untuk menaik secara terus menerus.Dalam kamus Bank Indonesia, Inflasi diartikan sebagai keadaan perekonomian yang ditandai dengan kenaikan harga secara cepat sehingga berdampak pada menurunnya daya beli, sering pula diikuti menurunnya tingkat tabungan atau investasi karena meningkatnya konsumsi masyrakat.

\section{Hubungan NPF terhadap tingkat bagi hasil deposito mudharabah}

Arfiani dan Mulazid (2017), hasil penelitiannya menunjukkan bahwa rasio Non Performing Financing(NPF) berpengaruh signifikan terhadap tingkat bagi hasil tabungan deposito Mudharabah, yakni tinggi rendahnya rasio NPF bank syariah akan mempengaruhi tingkat bagi hasil yang akan diberikan kepada nasabah.

$\mathrm{H}_{1}$ : Non Performing Financing (NPF) secara parsial berpengaruh signifikan terhadap tingkat bagi hasil tabungan deposito mudharabah.

\section{Hubungan BOPO terhadap tingkat bagi hasil deposito mudharabah}

Hasil penelitian Nur dan Nasir (2014) dan juga Wirawan (2016), Biaya Operasional Pendapatan Operasional (BOPO) mempunyai pengaruh negatif dan signifikan terhadap tingkat bagi hasil tabungan deposito mudharabah, hal tersebut menjelaskan bahwa semakin 
Halimatussa'idah, et al/Jurnal Ekonomi Syariah Teori dan Terapan Vol. 6 No. 7 Juli 2019: 1348-1364; ANALISIS FAKTOR - FAKTOR YANG MEMPENGARUHI TINGKAT BAGI HASIL TABUNGAN DEPOSITO MUDHARABAH PADA PERBANKAN SYARIAH DI INDONESIA PERIODE 2012 -2016

tinggi BOPO akan menurunkan tingkat bagi hasil yang akan diberikan kepada nasabah.

$\mathrm{H}_{2}$ : Biaya Operasional Pendapatan Operasional (BOPO) secara parsial berpengaruh signifikan terhadap tingkat bagi hasil tabungan deposito mudharabah.

\section{Hubungan BI Rateterhadap tingkat bagi hasil deposito mudharabah}

Hamzah (2015), hasil penelitiannya menjelaskan bahwa terdapat pengaruh positif signifikan antara suku bunga terhadap bagi hasil deposito. Hal tersebut juga dijelaskan dalam penelitian Chong dan Liu (2008), bahwa simpanan mudharabah dan tabungan al-wadiah tidak "bebas bunga," dan tingkat bagi hasilnya berhubungan erat dengan suku bunga deposito konvensional. Dikarenakan persaingan dari perbankan konvensional, imbal hasil pada rekening simpanan Islam secara efektif dipatok berdasarkan imbal hasil deposito perbankan konvensional.

$\mathrm{H}_{3}$ : $\mathrm{BI}$ Rate secara parsial berpengaruh signifikan terhadap tingkat bagi hasil tabungan deposito mudharabah.

\section{Hubungan inflasi terhadap tingkat bagi hasil deposito mudharabah}

Arif (2011), hasil penelitiannya menunjukkan bahwa terdapat pengaruh negatif dan signifikan inflasi terhadap tingkat bagi hasil deposito mudharabah. Ketika terjadi peningkatan pada inflasi, maka akan menurunkan tingkat bagi hasil deposito mudharabah bank syariah.

$$
\mathrm{H}_{4} \text { : Inflasi secara parsial }
$$
berpengaruh signifikan terhadap tingkat bagi hasil tabungan deposito mudharabah.

\section{Hubungan NPF, BOPO, BI Rate dan Inflasi Secara Simultan Terhadap Tingkat Bagi Hasil Deposito mudharabah.}

Arfiani dan Mulazid (2017), hasil penelitiannya menunjukkan bahwa secara simultan FDR, NPF dan Inflasi berpengaruh signifikan.Farianto (2014), hasil penelitiannya menunjukkan bahwa secara simultan ROA, BOPO dan BI Rate berpengaruh signifikan.

$\mathrm{H}_{5}$ : Non Performing Financing (NPF), Biaya Operasional Pendapatan Operasional (BOPO), BI Rate dan Inflasi secara simultan berpengaruh signifikan terhadap tingkat bagi hasil tabungan deposito mudharabah.

\section{Model Analisis}

$Y_{\text {it }}=\beta_{0}+\beta_{1}(X 1)_{+}+\beta_{2}(X 2)_{+}+\beta_{3}(X 3)_{+}+\beta_{4}(X 4)_{+}+\varepsilon$

Keterangan :

$\mathrm{Y}=$ Variabel Dependen ( Tingkat Bagi Hasil Tabungan Deposito Mudharabah)

$$
\begin{array}{ll}
\beta_{0} & =\text { konstanta } \\
\beta_{1} & =\text { Koefesien Regresi NPF } \\
X_{1} & =\text { Variabel Independen (NPF) } \\
\beta_{2} & =\text { Koefesien Regresi BOPO } \\
X_{2} & =\text { Variabel Independen (BOPO) } \\
\beta_{3} & =\text { Koefesien Regresi BI Rate } \\
X_{3} & =\text { Variabel Independen (BI Rate) } \\
\beta_{4} & =\text { Koefesien Regresi Inflasi } \\
X 4 & =\text { Variabel Independen (Inflasi) }
\end{array}
$$


Halimatussa'idah, et al/Jurnal Ekonomi Syariah Teori dan Terapan Vol. 6 No. 7 Juli 2019: 1348-1364; ANALISIS FAKTOR - FAKTOR YANG MEMPENGARUHI TINGKAT BAGI HASIL TABUNGAN DEPOSITO MUDHARABAH PADA PERBANKAN SYARIAH DI INDONESIA PERIODE 2012 -2016

$\varepsilon \quad=$ error

III. METODE PENELITIAN

\section{Pendekatan Penelitian}

Pendekatan yang digunakan pada penelitian ini adalah pendekatan kuantitatif.

\section{Identifikasi Variable}

Berdasarkan rumusan masalah penelitian, maka variabel dependen dalam penelitian ini adalah tingkat bagi hasil tabungan deposito mudharabah dan variable independen adalah Non Performing Financing (NPF), Biaya Operasional Pendapatan Operasional (BOPO), BI Rate dan Inflasi.

\section{Definisi Operasional}

1. Non Perfoming Financing (NPF) ( $x 1$ ) NPF adalah rasio yang menggambarkan besarnya pembiayaan bermasalah dengan total pembiayaan yang disalurkan oleh bank syariah.

2. Beban Operasional Pendapatan Operasional (BOPO) (X2)

BOPO (Biaya Operasional

Pendapatan Operasional) merupakan rasio efisiensi yang digunakan untuk mengukur kemampuan manajemen bank dalam mengendalikan biaya operasional terhadap pendapatan operasionalnya.

3. Bi Rate (X3)

Menurut kamus Bank Indonesia, BI Rate merupakan suku bunga kebijakan yang mencerminkan sikap atau stance kebijakan moneter yang ditetapkan oleh Bank Indonesia yang diumumkan ke publik.

4. Inflasi (X4)
Inflasi adalah kecenderungan dari harga - harga untuk menaik secara terus menerus (Latumeirissa, 2012:22). Kenaikan dari satu dua jenis harga saja dan tidak menyeret harga barang lain tidak bisa disebut inflasi. Indikatornya adalah Indeks Harga Konsumen (IHK).

5. Tingkat Bagi Hasil Deposito Mudharabah (Y)

Tingkat Bagi Hasil adalah presentasi tingkat imbalan yang diberikan kepada nasabah dengan menggunakan akad Mudharabah pada deposito.

\section{Jenis Dan Sumber Data}

Metode pengumpulan data secara sekunder atau tidak langsung.Untuk data Non Performing Financing (NPF), Biaya Operasional Pendapatan Operasional (BOPO) dan tingkat bagi hasil tabungan deposito mudharabah diperoleh dari Statistik Perbankan Syariah (SPS) yang diterbitkan oleh OJK pada situs resmi OJK (www.ojk.go.id). Sedangkan data BI Rate dan Inflasi diperoleh dari situs resmi Bank Indonesia (www.bi.go.id).

\section{Populasi Dan Sampel}

Populasi yang digunakan dalam penelitian ini adalah Bank Umum Syariah (BUS) dan Unit Usaha Syariah (UUS) yang tercatat di Satatistik Perbankan Syariah terbitan OJK periode Januari 2012 Desember 2016.

Sampel yang digunakan dalam penelitian ini adalah sampel jenuh.Sampel jenuh adalah teknik penentuan sampel bila semua anggota populasi digunakan 
Halimatussa'idah, et al/Jurnal Ekonomi Syariah Teori dan Terapan Vol. 6 No. 7 Juli 2019: 1348-1364; ANALISIS FAKTOR - FAKTOR YANG MEMPENGARUHI TINGKAT BAGI HASIL TABUNGAN DEPOSITO MUDHARABAH PADA PERBANKAN SYARIAH DI INDONESIA PERIODE 2012 -2016

sebagai sampel (Sugiyono, 2015:68). Maka sample penelitian ini adalah Bank Umum Syariah (BUS) dan Unit Usaha Syariah (UUS) yang tercatat di Satatistik Perbankan Syariah terbitan OJK periode Januari 2012 - Desember 2016.

Teknik Analisis

Teknik analisis data yang digunakan dalam penilitian ini adalah analisis regresi data time series. Teknik analisis regresi data time series merupakan urutan pengamatan pada beberapa fenomena yang diamati secara berkala. Jangka waktu yang digunakan biasanya berupa data tahunan, kuartalan, maupun bulanan.Alat statistik yang digunakan dalam penelitian kalini ini adalah eviews 9.0 .

\section{HASIL PEMBAHASAN}

\section{Uji normalitas}

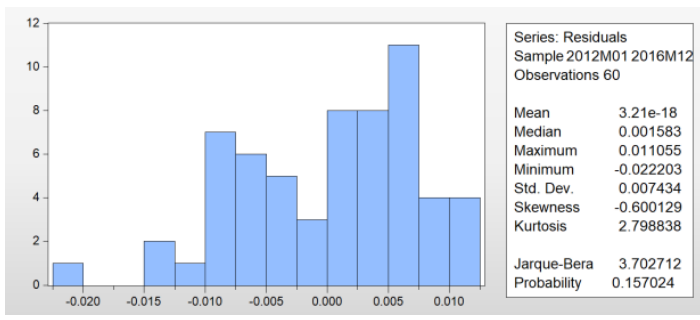

Sumber : Hasil Uji dengan eviews.

\section{Gambar 1.}

\section{Hasil Uji Normalitas}

Uji normalitas menggunakan uji statistik Jarque-Bera. Menurut Winarno (2009:5.39). Hasil uji normalitas menggunakan eviews menunjukkan bahwa nilai uji statistik Jarque-Bera sebesar 3.702712 dengan p-value 0.157024.nilaip-value sebesar $0.157024>$ 0.05, sehingga dapat ditarik kesimpulan bahwa data yang digunakan dalam penelitian ini terdistribusi normal.

Uji heteroskidastisitas

Tabel 3.

Hasil Uji Heteroskidastisitas

\begin{tabular}{|l|l|l|l|}
\hline \multicolumn{3}{|l|}{ Heteroskidasticity Test : Glesjer } \\
\hline F-Statistic & 0.291529 & $\begin{array}{l}\text { Prob. } \\
\text { F(4.55) }\end{array}$ & 0.8822 \\
\hline $\begin{array}{l}\text { Obs *R- } \\
\text { Squared }\end{array}$ & 1.245715 & $\begin{array}{l}\text { Prob. Chi- } \\
\text { Square }\end{array}$ & 0.8705 \\
(4) & \\
\hline
\end{tabular}

Sumber: Hasil pengolahan data dengan eviews.

Pada penelitian ini, uji heteroskidastisitas menggunakan uji statistik glesjer.penarikan kesimpulannya adalah apabila nilai p-value > 0.05 maka model regresi pada penelitian ini bebas asumsi heteroskidastisitas.

Tabel 3 menunjukkan hasil perhitungan uji heteroskidastisitas dengan uji statistic glesjer menunjukkan nilai $p$ value Obs *R-squared sebesar 0.8705.Nilai p-value sebesar $0.8705>0.05$, maka dapat disimpulkan bahwa model regresi dalam penelitian ini bebas asumsi heteroskidastisitas.

Uji Multikolineritas

Untuk mengetahui apakah terdapat multikolineritas menggunakan uji VIF atau Variance Inflation Factor. Multikolineritas terjadi apabila nilai tolerance $\leq 0.10$ atau sama dengan VIF $\geq$ 10 (Ghozali, 2011:106). Hasil pengujian multikolineritas pada penelitian ini ditunjukkan pada tabel berikut : 
Halimatussa'idah, et al/Jurnal Ekonomi Syariah Teori dan Terapan Vol. 6 No. 7 Juli 2019: 1348-1364; ANALISIS FAKTOR - FAKTOR YANG MEMPENGARUHI TINGKAT BAGI HASIL TABUNGAN DEPOSITO MUDHARABAH PADA PERBANKAN SYARIAH DI INDONESIA PERIODE 2012 -2016

Tabel 4.

Hasil Uji Multikolineritas

\begin{tabular}{|c|c|c|}
\hline Variabel & VIF & Keterangan \\
\hline NPF & 6.125145 & Bebas Multikol \\
\hline BOPO & 4.485279 & Bebas Multikol \\
\hline BI Rate & 2.975805 & Bebas Multikol \\
\hline INFLASI & 2.445769 & Bebas Multikol \\
\hline
\end{tabular}

Sumber : Hasil pengolahan data dengan eviews.

Tabel 4 diatas dapat menunjukkan bahwa semua variabel bebas, yakni NPF, BOPO, BI Rate dan Inflasi memiliki nilai Variance Inflation Factors (VIF) $\leq 10$. Sehingga dapatdisimpulkan bahwa semua variabel bebas dalam penelitian ini bebas multikolineritas.

Autokorelasi

Tabel 5.

Hasil Uji Autokorelasi

\begin{tabular}{|c|c|}
\hline Indikator & Hasil \\
\hline $\begin{array}{c}\text { Durbin - Watson } \\
\text { Stat }\end{array}$ & 0.611255 \\
\hline
\end{tabular}

Sumber : hasil pengolahan data dengan eviews.

Menurut Santoso (2001:219), kriteria yang digunakan dalam uji autokorelasi adalah $-2<$ Durbin-Watson $<2$.Apabila hasil uji Durbin-Watson memenuhi asumsi tersebut, maka tidak terjadi autokorelasi.Pada tabel 5 diatas, hasil uji autokorelasi angka Durbin-Watson sebesar 0.611255 . Hasil pengolahan data tersebut menunjukkan hasil uji Durbin-Watson memenuhi kriteria -2 <Durbin-Watson < 2.Dapat disimpulkan bahwa model regresi dalam penelitian ini bebas autokorelasi.

Hasil Uji Linearitas
Tabel 6.

Hasil Uji Linearitas

\begin{tabular}{|l|c|c|c|}
\hline & Value & df & Probability \\
\hline F- & 0.329794 & $(1.54)$ & 0.5682 \\
statistic & & & \\
\hline
\end{tabular}

Sumber : hasil olah data dengan eviews.

Pada table 6 diatas menjelaskan

bahwa hasil uji linearitas dengan menggunakan Ramsey Reset Test menunjukkan nilai $p$-value sebesar 0.5682 $>0.05$, maka dari itu dapat disimpulkan bahwa model dalam penelitian kali ini berbentuk linear.

Analisis Koefesien Determinasi ( $\left.\mathbf{R}^{2}\right)$

Tabel 7.

Hasil Analisis Koefesien Determinasi ( $\left.\mathbf{R}^{2}\right)$

\begin{tabular}{|l|c|c|}
\hline & $\begin{array}{c}\text { R- } \\
\text { Squared }\end{array}$ & $\begin{array}{c}\text { Adjusted R- } \\
\text { Squared }\end{array}$ \\
\hline $\begin{array}{l}\text { Hasil Analisis } \\
\text { Koefesien } \\
\text { Determinasi }\left(R^{2}\right)\end{array}$ & 0.529038 & 0.494786 \\
\hline
\end{tabular}

Sumber : hasil olah data dengan eviews

Pada tabel 7 menunjukkan bahwa nilai R-squared $\left(R^{2}\right)$ pada penelitian kali ini sebesar 0.529038 atau sebesar 53\%. Artinya bahwa variabel independen Non Performing Financing (NPF), Beban Operasional Pendapatan Operasional (BOPO), BI Rate dan inflasi dapat menjelaskan variabel dependen tingkat bagi hasil deposito mudharabah sebesar $53 \%$, dan sisanya sebesar $47 \%$ dijelaskan oleh variabel independen lain yang tidak digunakan dalam penelitian ini.

\section{Regresi Time Series}

Persamaan regresi time series sebagai berikut: 
Halimatussa'idah, et al/Jurnal Ekonomi Syariah Teori dan Terapan Vol. 6 No. 7 Juli 2019: 1348-1364; ANALISIS FAKTOR - FAKTOR YANG MEMPENGARUHI TINGKAT BAGI HASIL TABUNGAN DEPOSITO MUDHARABAH PADA PERBANKAN SYARIAH DI INDONESIA PERIODE 2012 -2016

Bagi hasil $+=0.032198+N P F_{\dagger} 0.383124-$ $\mathrm{BOPO}_{+} 0.018066+\mathrm{BIRATE}_{+} 0.718737-$ INFLASI+0.277951

Berikut penjelasan dari persamaan tersebut:

1. Konstanta sebesar 0.032198 menunjukkan apabila variabel independen NPF, BOPO, BI Rate dan inflasi besarnya nol atau konstan maka nilai dari tingkat bagi hasil deposito mudharabah adalah sebesar 0.032198.

2. Koefesien NPF sebesar 0.383124, yang berarti apabila NPF ditingkatkan satu satuan maka tingkat bagi hasil deposito mudharabahakan naik sebesar 0.383124 dan begitu pula sebaliknya dengan asumsi variabel lain konstan.

3. Koefesien BOPO sebesar -0.018066, yang berarti apabila BOPO ditingkatkan satu satuan maka tingkat bagi hasil deposito mudharabahakan turun sebesar 0.018066 dan begitu pula sebaliknya dengan asumsi variabel lain konstan.

4. Koefesien BI Rate sebesar 0.718737, yang berarti apabila BI Rateditingkatkan satu satuan maka tingkat bagi hasil deposito mudharabahakan naik sebesar 0.718737 dan begitu pula sebaliknya dengan asumsi variabel lain konstan.

5. Koefesien inflasi sebesar -0.277951, yang berarti apabila inflasi ditingkatkan satu satuan maka tingkat bagi hasil deposito mudharabahakan turun sebesar 0.277951 dan begitu pula sebaliknya dengan asumsi variabel lain konstan.

\section{Uji F (simultan)}

Uji $F$ digunakan untuk menguji variabel hubungan secara simultan atau bersama - sama.

Tabel 8.

Hasil Uji F (simultan)

\begin{tabular}{|c|c|c|}
\hline & F-Statistic & $\begin{array}{l}\text { Prob (F- } \\
\text { Statistic) }\end{array}$ \\
\hline Hasil Uji F & 0.007700 & 0.000000 \\
\hline
\end{tabular}

Sumber: hasil olah data dengan eviews

Pada tabel 8 menunjukkan bahwa hasil uji $F$ sebesar 0.007700 dengan tingkat signifikansi 0.000000. Nilai signifikansi lebih kecil dari 0.05 sehingga dapat disimpulkan bahwa variabel independen Non Performing Financing (NPF), Beban Operasional Pendapatan Operasional (BOPO), BI Rate dan inflasi berpengaruh signifikan secara bersama - sama (simultan) terhadap menjelaskan variabel dependen tingkat bagi hasil deposito mudharabah. Maka hal tersebut menunjukkan bahwa menerima $\mathrm{H}_{5}$ dan menolak Ho.

Uji † (Parsial)

Tabel 9.

Hasil Uji Parsial

\begin{tabular}{|c|c|c|}
\hline Variable & t-Statistic & Prob \\
\hline NPF & 1.849410 & 0.0698 \\
BOPO & -0.826851 & 0.4119 \\
BIRATE & 3.860007 & 0.0003 \\
INFLASI & -3.138529 & 0.0027 \\
C & 1.988763 & 0.0517 \\
\hline
\end{tabular}

Sumber: hasil olah data dengan eviews 
Halimatussa'idah, et al/Jurnal Ekonomi Syariah Teori dan Terapan Vol. 6 No. 7 Juli 2019: 1348-1364; ANALISIS FAKTOR - FAKTOR YANG MEMPENGARUHI TINGKAT BAGI HASIL TABUNGAN DEPOSITO MUDHARABAH PADA PERBANKAN SYARIAH DI INDONESIA PERIODE 2012 -2016

Tabel 9 menunjukkan hasil uji † pada penelitian ini adalah sebagai berikut:

1. Non Performing Financing (NPF)

Hasil uji $\dagger$ variabel NPF menghasilkan nilai signifikansi sebesar 0.0698 lebih dari 0.05. Maka dapat simpulkan bahwa variabel NPF secara parsial berpengaruh positif dan tidak signifikan terhadap tingkat bagi hasil deposito mudharabah.

2. Beban Operasional Pendapatan Operasional (BOPO)

Hasil uji † variabel BOPO menghasilkan nilai signifikansi sebesar 0.4119 lebih dari 0.05.Maka dapat disimpulkan bahwa variabel BOPO secara parsial berpengaruh negatif dan tidak signifikan terhadap tingkat bagi hasil deposito mudharabah.

3. BI Rate

Hasil uji † variabel BI Rate menghasilkan nilai signifikansi sebesar 0.0006 kurang dari 0.05.Maka dapat disimpulkan bahwa variabel BI Rate secara parsial berpengaruh positif dan signifikan terhadap tingkat bagi hasil deposito mudharabah.

4. Inflasi

Hasil uji † variabel Inflasimenghasilkan nilai signifikansi sebesar 0.0027 kurang dari 0.05.Maka dapat disimpulkan bahwa inflasi berpengaruh negatif dan signifikan terhadap tingkat bagi hasil deposito mudharabah.

Pembahasan

Pengaruh NPF secara parsial terhadap tingkat bagi hasil deposito mudharabah
Hasil pengujian hipotesis pengaruh NPF secara parsial, nilai uji † variabel NPF adalah sebesar 1.849410 dengan tingkat signifikansi 0.0698 .Nilai siginifikansi 0.0698 lebih besar dari 0.05, maka dari itu dapat disimpulkan bahwa variabel NPF tidak berpengaruh terhadap tingkat bagi hasil deposito mudharabah.Hasil penelitian ini sejalan dengan Nofianti dkk (2015) bahwa NPF berpengaruh positif dan tidak signifikan dengan tingkat bagi hasil deposito mudharabah. Hasil peneltian ini menjelaskan bahwa rasio NPF berpengaruh positif dan tidak signifikan. Nofianti dkk (2015) dan Dhamayanti (2016) berpendapat tidak sigfinikannya NPF adalah bank syariah sudah selektif dalam menyalurkan dana pembiayaan, bank syariah telah memiliki cadangan yang baik, penanganan yang baik pada pembiayaan bermasalah pada bank syariah dan kecilnya moral hazard pada bank syariah. Selain itu, bank syariah juga dapat memberikan subsidi bagi hasil kepada nasabah.

Menurut Muhamad (2012:117), untuk mencegah nasabah memindahkan dana nya pada bank konvensional, maka bank syariah dapat melakukan pengurangan porsi bagi hasil untuk bank syariah sehingga posi bagi hasil untuk nasabah akan meningkat. Untuk tetap bersaing dengan bank konvensional, pihak bank syariah dapat memberikan special nisbah yang kira - kira indikasinya sama dengan special rate pada bank konvensional. Sehingga dengan adanya 
Halimatussa'idah, et al/Jurnal Ekonomi Syariah Teori dan Terapan Vol. 6 No. 7 Juli 2019: 1348-1364; ANALISIS FAKTOR - FAKTOR YANG MEMPENGARUHI TINGKAT BAGI HASIL TABUNGAN DEPOSITO MUDHARABAH PADA PERBANKAN SYARIAH DI INDONESIA PERIODE 2012 -2016

tindakan tersebut meskipun rasio NPF mengalami peningkatan maka tidak akan mengurangi atau menurunkan tingkat bagi hasil yang akan diberikan kepada nasabah. Tindakan tersebut dilakukan untuk menjaga loyalitas nasabah terhadap bank syariah melihat kondisi saat ini bank syariah masih bersaing dengan bank konvensional.

Menurut Djamil (2014: 75), Islam mengajarkan beberapa etika ketika melakukan utang piutang diantara sesama manusia, salah satunya adalah menepati janji. Apabila telah terikat perjanjian hutang atau pembiayaan dalam jangka waktu tertentu, maka wajib ditepati janji tersebut untuk membayar hutang sesuai dengan perjanjian awal. Menepati janji adalah wajib dan setiap orang bertanggung jawab terhadap janji - janjinya begitu pula dengan utang piutang

Tingkat NPF selama periode yang diteliti Januari 2012 sampai Desember 2016 menunjukkan nilai yang cukup baik. Hal tersebut ditandai dengan rata - rata NPF bank syariah pada periode tersebut sebesar $4.02 \%$ dibawah standar maksimal yang telah ditetapkan Bank Indonesia yakni sebesar 5\%. Seperti yang sudah dijelaskan diatas, tidak siginifikannya variabel NPF dikarenakan pemberian subsidi bagi hasil atau special rate kepada nasabah karena adanya persaingan dengan bank konvensional sehingga NPF berpengaruh namun tidak signifikan terhadap tingkat bagi hasil deposito mudharabah.

\section{Pengaruh BOPO secara parsial terhadap} tingkat bagi hasil deposito mudharabah

Hasil pengujian hipotesis pengaruh BOPO secara parsial nilai uji $t$ variabel BOPO adalah sebesar -0.826851 dengan tingkat signifikansi 0.4119 .nilai signifikansi sebesar 0.4119 lebih besar dari 0.05, maka dapat ditarik kesimpulan bahwa variabel BOPO tidak berpengaruh terhadap tingkat bagi hasil deposito mudharabah.

Hasil penelitian ini menolak penelitian Syafira (2014) bahwa BOPO berpengaruh negatif signifikan terhadap tingkat bagi hasil deposito mudharabah dan sejalan dengan penelitian Isna dan Sunaryo (2012) bahwa BOPO berpengaruh negatif dan tidak signifikan tingkat bagi hasil deposito mudharabah. Rasio BOPO digunakan untuk mengukur efisiensi bank syariah. Semakin efisien bank syariah maka akan memberikan tingkat bagi hasil yang tinggi untuk nasabah, dan juga sebaliknya. Dalam penelitian ini rasio BOPO berpengaruh tidak signifikan, hal ini mengindikasikan bahwa BOPO bukan faktor yang sangat dipertimbangkan dalam menentukan tingkat bagi hasil deposito mudharabah.

Kondisi perbankan syariah di Indonesia yang masih dalam tahap berkembang mengakibatkan beban operasional masih cukup tinggi. Untuk menghindari turunnya tingkat bagi hasil yang akan dibagikan kepada nasabah, maka bank syariah memberikan subsidi 
Halimatussa'idah, et al/Jurnal Ekonomi Syariah Teori dan Terapan Vol. 6 No. 7 Juli 2019: 1348-1364; ANALISIS FAKTOR - FAKTOR YANG MEMPENGARUHI TINGKAT BAGI HASIL TABUNGAN DEPOSITO MUDHARABAH PADA PERBANKAN SYARIAH DI INDONESIA PERIODE 2012 -2016

tingkat bagi hasil. Hal tersebut dilakukan untuk menghindari Displacement Commercial Risk (DCR)yang disebabkan oleh adanya potensi nasabah memindahkan dana nya yang didorong oleh tingkat bonus atau bagi hasil yang lebih rendah dari tingkat suku bunga. Menurut Solissa (2017), Displacement Commercial Risk (DCR) yaitu perubahan perilaku nasabah, dimana nasabah dana pihak ketiga memindahkan ke bank konvensional karena tingkat suku bunga tabungan maupun deposito lebih tinggi dibandingkan equivalent rate bagi hasil pada bank syariah. Bank Syariah dapat memberikan special rate atau mitigasi dengan sistem Profit Equalization Reserve (PER) dengan tujuan agar tingkat bagi hasil yang diberikan kepada nasabah masih kompetitif dengan suku bunga bank konvensional.

$$
\text { Rata - rata (mean) rasio BOPO }
$$
pada periode yang diteliti sebesar $85.40 \%$ tapi masih berada diatas rata - rata standar BOPO yang ditetapkan oleh Surat Edaran Bank Indonesia No.13/24/DPNP. 25 Oktober 2011 yakni $\leq$ 83\%.Tingginya rasio BOPO bank syariah menyebabkan turunnya tingkat bagi hasil deposito.Namun, hal tersebut tidak signifikan dikarenakan untuk menghindari risiko nasabah memindahkan dana nya dan juga agar dapat tetap bersaing dengan bank konvensional, maka bank syariah memberikan special rate kepada nasabah.
Pengaruh BI Rate secara parsial terhadap tingkat bagi hasil deposito mudharabah

Hasil pengujian hipotesis pengaruh $\mathrm{BI}$ Rate secara parsial nilai uji † variabel $\mathrm{Bl}$ Rate adalah sebesar 3.860007 dengan tingkat signifikansi 0.0003 . Nilai siginifikansi 0.0003 lebih kecil dari 0.05 , maka dari itu dapat disimpulkan bahwa variabel BI Rate berpengaruh positif dan signifikan terhadap tingkat bagi hasil deposito mudharabah. Sehingga hasil dalam penelitian ini, apabila BI Rate meningkat maka tingkat bagi hasil deposito mudharabah akan meningkat. Hasil penelitian ini juga menjelaskan bahwa variabel BI Rate merupakan variabel yang paling mempengaruhi dan setiap terjadi kenaikan satu satuan maka akan meningkatkan bagi hasil deposito mudharabah sebesar 0.718737 .

BI Rate merupakan suku bunga kebijakan dengan tenor satu bulan yang dikeluarkan oleh Bank Indonesia selaku pengendali moneter.Dalam Islam, terdapat pelarangan penggunaan suku bunga pada kegiatan perbankan. Allah SWT dengan tegas melarang umat manusia melaksanakan praktik ribawi, sebagaimana firman Allah SWT Surat AlBaqarah ayat 278 - 279 bagi siapa saja yang masih melaksanakan praktik ribawi adalah

Artinya: 278. Hai orang-orang yang beriman, bertakwalah kepada Allah dan tinggalkan sisa Riba lyang belum dipungut) jika kamu orang-orang yang beriman. 279. Maka jika kamu tidak 
Halimatussa'idah, et al/Jurnal Ekonomi Syariah Teori dan Terapan Vol. 6 No. 7 Juli 2019: 1348-1364; ANALISIS FAKTOR - FAKTOR YANG MEMPENGARUHI TINGKAT BAGI HASIL TABUNGAN DEPOSITO MUDHARABAH PADA PERBANKAN SYARIAH DI INDONESIA PERIODE 2012 -2016

mengerjakan (meninggalkan sisa riba), Maka ketahuilah, bahwa Allah dan RasulNya akan memerangimu. dan jika kamu bertaubat (dari pengambilan riba), Maka bagimu pokok hartamu; kamu tidak Menganiaya dan tidak (pula) dianiaya.

Berdasarkan hasil perhitungan dalam penelitian kali ini, BI Rate memiliki hasil yang signifikan terhadap tingkat bagi hasil deposito mudharabah, maka dapat disimpulkan bahwa suku bunga masih dijadikan acuan perbankan syariah dalam menentukan tingkat bagi hasil yang akan diberikan kepada nasabah. Hasil penelitian kali ini sejalan dengan Chong dan Liu (2008), Farianto (2011) dan Hamzah (2015) hasil penelitiannya menjelaskan bahwa terdapat pengaruh positif signifikan antara suku bunga terhadap bagi hasil deposito. Tingkat bagi hasil bank syariah berhubungan erat dengan suku bunga deposito konvensional dikarenakan persaingan dari perbankan konvensional, imbal hasil pada rekening simpanan syariah secara efektif dipatok berdasarkan imbal hasil deposito perbankan konvensional.

Di Indonesia, yang memiliki kedudukan sebagai bank sentral adalah Bank Indonesia. Menurut UU No 21 Tahun 2008, Bank Indonesia adalah Bank Sentral Republik Indonesia sebagaimana dimaksud dalam Undang - Undang Negara Republik Indonesia 1945. Salah satu fungsi Bank Indonesia menurut UU No. 23 Tahun 1999 tentang Bank Indonesia adalah menetapkan dan melaksankan kebijakan moneter. Seluruh kegiatan baik bank syariah maupun bank konvensional berada dibawah kebijakan Bank Indonesia.Seluruh peraturan dalam bentuk PBI (Peraturan Bank Indonesia) maupun SE (Surat Edaran) bersifat wajib dilaksanakan.Maka dari itu, dalam menentukan suku bunga pada bank konvensional dan tingkat bagi hasil pada bank syariah masih mengacu pada BI Rate.

Pengaruh Inflasi secara parsial terhadap tingkat bagi hasil deposito mudharabah

Hasil pengujian hipotesis pengaruh inflasi secara parsial. Nilai uji $\dagger$ variabel inflasi adalah sebesar -3.138529 dengan tingkat signifikansi 0.0027 .Nilai siginifikansi 0.0027 lebih kecil dari 0.05, maka dari itu dapat disimpulkan bahwa variabel inflasi berpengaruh negatif dan signifikan terhadap tingkat bagi hasil deposito mudharabah. Sehingga hasil dalam penelitian ini, apabila inflasi meningkat maka tingkat bagi hasil deposito mudharabah akan menurun. Hasil penelitian ini juga menjelaskan bahwa setiap terjadi kenaikan satu satuan inflasi maka akan menurunkan bagi hasil deposito mudharabah sebesar -0.277951.

Hasil penelitian ini sejalan dengan penelitian terdahulu Ulfah (2011) dan Arif (2011) bahwa inflasi memiliki pengaruh negatif dan signifikan terhadap tingkat bagi hasil deposito mudharabah. Jika inflasi mengalami fluktuasi, maka kegiatan perekonomian cenderung menyesuaikan dengan kondisi yang terjadi, begitu pula 
Halimatussa'idah, et al/Jurnal Ekonomi Syariah Teori dan Terapan Vol. 6 No. 7 Juli 2019: 1348-1364; ANALISIS FAKTOR - FAKTOR YANG MEMPENGARUHI TINGKAT BAGI HASIL TABUNGAN DEPOSITO MUDHARABAH PADA PERBANKAN SYARIAH DI INDONESIA PERIODE 2012 -2016

dengan sektor perbankan. Pada saat perekonomian menurun yang mana salah satu indikatornya adalah inflasi yang tinggi, maka tingkat bagi hasil deposito mudharabah yang ditetapkan bank syariah juga akan menurun. Menurut Arif (2011), turunnya daya beli masyarakat akibat dari kenaikan harga pada saat inflasi menunjukkan bahwa stabilitas harga sebagai salah satu faktor yang mempengaruhi hasil pembagian keuntungan perbankan syariah atas penentuan tingkat bagi hasil deposito. Tingkat inflasi yang lebih tinggi, maka akan menurunkan tingkat bagi hasil deposito yang akan dibagikan kepada deposan.

Pada periode Januari 2012 sampai Desember 2016, tingkat inflasi cenderung berfluktuatif dan mencapai kenaikan melebihi target yang sudah ditetapkan pada periode 2013 dan 2014.Setelah itu, inflasi mengalami penurunan yang cukup signifikan untuk periode selanjutnya.Meskipun tingkat inflasi negara Indonesia masih cenderung low inflation, namun pergerakan inflasi yang mencerminkan kondisi perkonomian negara ini masih menjadi faktor penentu bank syariah dalam menentukan tingkat bagi hasil deposito mudharabah.

Pengaruh NPF, BOPO, BI Rate dan Inflasi secara simultan terhadap tingkat bagi hasil deposito mudharabah

Hasil uji hipotesis secara simultan menunjukkan bahwa Non Performing Financing(NPF), Beban Operasional
Pendapatan Operasional (BOPO), BI Rate dan inflasi secara bersama - sama (simultan) berpengaruh signifikan terhadap tingkat bagi hasil deposito mudharabah. Hal tersebut ditunjukkan nilai uji $F$ adalah 0.007700 dengan signifikansi $0.0000(<0.05)$, maka variabel independen dalam penelitian ini berpengaruh secara simultan terhadap variabel dependen.

\section{v. SIMPULAN DAN SARAN}

\section{Simpulan}

Berdasarkan hasil penelitian yang dilakukan maka dapat diambil kesimpulan sebagai berikut :

1. Non Performing Financing(NPF) berpengaruh positif dan tidak signifikan terhadap tingkat bagi hasil deposito mudharabah perbankan syariah di Indonesia periode Januari 2012 sampai Desember 2016.

2. Beban Operasional Pendapatan Operasional (BOPO) berpengaruh negatif dan tidak signifikan terhadap tingkat bagi hasil deposito mudharabah perbankan syariah di Indonesia periode Januari 2012 sampai Desember 2016.

3. BI Rate berpengaruh positif dan signifikan terhadap tingkat bagi hasil deposito mudharabah perbankan syariah di Indonesia periode Januari 2012 sampai Desember 2016.

4. Inflasiberpengaruh negatif dan signifikan terhadap tingkat bagi hasil deposito mudharabah perbankan 
Halimatussa'idah, et al/Jurnal Ekonomi Syariah Teori dan Terapan Vol. 6 No. 7 Juli 2019: 1348-1364; ANALISIS FAKTOR - FAKTOR YANG MEMPENGARUHI TINGKAT BAGI HASIL TABUNGAN DEPOSITO MUDHARABAH PADA PERBANKAN SYARIAH DI INDONESIA PERIODE 2012 -2016

syariah di Indonesia periode Januari 2012 sampai Desember 2016.

5. Non Performing Financing(NPF), Beban Operasional Pendapatan Operasional (BOPO), BI Rate dan Inflasi berpengaruh signifikan secara simultan berpengaruh terhadap tingkat bagi hasil deposito mudharabah perbankan syariah di Indonesia periode Januari 2012 sampai Desember 2016.

6. Nilai uji analisis koefesien dterminasi $\left(R^{2}\right)$ sebesar $53 \%$ dijelaskan oleh variabel Non Performing Financing(NPF), Beban Operasional Pendapatan Operasional (BOPO), BI Rate dan Inflasi. Sedangkan sisanya $47 \%$ dijelaskan oleh variabel lain yang tidak diuji dalam penelitian ini.

\section{Saran}

Berdasarkan penelitian yang telah dilakukan, maka saran yang dapat diberikan adalah sebagai berikut :

1. Perbankan syariah terutama BUS dan UUS yang menajadi objek penelitian kali ini diharapkan dapat mengefisiensikan rasio BOPO dikarenakan masih cukup tinggi. Selain itu, tetap menjaga rasio NPF $<5 \%$ sesuai dengan yang ditetapkan Bank Indonesia. Serta tidak bergantung dengan suku bunga.

2. Saran untuk penelitian selanjutnya adalah dapat menggunakan variabel lain yang tidak digunakan dalam penelitian ini seperti FDR, CAR dan ROA dari sisi internal bank, serta faktor ekternal yang dapat digunakan adalah nilai tukar, GDP dan lain sebagainya. Selain itu dapat menggunakan objek Bank Umum Syariah (BUS) secara individual serta memperbanyak jumlah tahun yang diteliti.

\section{DAFTAR PUSTAKA}

Antonio, Muhammad Syafii. (2017). Bank Syariah dari Teori ke Praktik.Jakarta : Gema Insani.

Arif, Mohammad Nur Rianto Al. (2011).The Effect Of Macro Economic On Profit - Sharing Yield Pricing. Yogyakarta: Economic Journal Of Emerging Markets. Vol.3.No 3. HIm $234-244$.

Bank Indonesia.(2006). Peraturan Bank Indonesia Nomor 8/21/PBI/2006.Jakarta : Bank Indonesia.

(2007). Lampiran Surat Edaran Bank Indonesia Nomor 9/24/DPbs/2007.Jakarta : Bank Indonesia.

(2001). Peraturan Bank Indonesia Nomor 3/25/PBI/2001.Jakarta : Bank Indonesia.

(2011). Surat Edaran Bank Indonesia Nomor 13/24/DPNP 25 Oktober 2011.Jakarta : Bank Indonesia.

Chong, Beng Soon dan Liu, Ming-Hua. (2008). Islamic Banking : Interest Free or Interest-Based?. Elsevier : Pasific-Basin Financing Journal 125 $-144$. 
Halimatussa'idah, et al/Jurnal Ekonomi Syariah Teori dan Terapan Vol. 6 No. 7 Juli 2019: 1348-1364; ANALISIS FAKTOR - FAKTOR YANG MEMPENGARUHI TINGKAT BAGI HASIL TABUNGAN DEPOSITO MUDHARABAH PADA PERBANKAN SYARIAH DI INDONESIA PERIODE 2012 -2016

Departemen Agama, RI. (2012). The Noble Qur'an. Depok : Al-Huda Kelompok Gema Insani.

Dewan Syariah Nasional MUI.(2000). Fatwa DSN Nomor 03/DSN-MUI/2000 Tentang Deposito.Jakarta : Dewan Syariah Nasional MUI.

Djamil, Faturrahman.(2014).Penyelesaian Pembiayaan Bermasalah di Bank Syariah. Jakarta : Sinar Grafika.

Farianto, Agus. (2014). Analisis Pengaruh Return On Asset (ROA), BOPO dan BI Rate Terhadap Tingkat Bagi Hasil Deposito Mudharabah Pada Bank Umum Syariah di Indoneisa Tahun 2012 - 2013. Kudus : Equilibrium. Vol 2. No.1

Ghozali, Imam. (2011). Aplikasi Analisis Multivariate dengan Program IBM SPSS 19.Semarang: Badan Penerbit Universitas Diponegoro.

Hamza, Hichem. (2015) .Does Investment Deposit Return in Islamic Bank Reflects PLS Principle?.Eelsevier : Borsa Istanbul Review 16-1 32-42.

Sudarsono, Heri. (2009) .Dampak Krisis Kevangan Global Terhadap Perbankan di Indonesia : Perbandingan Antara Bank Konvensional dan Bank Syariah. Yogayakarta : La Riba Jurnal Ekonomi Islam. Vol 3. No 1.

Ismail.(2014). Perbankan Syariah.Jakarta : Kencana Prenada Media.

K, Andryani Isna dan Sunaryo, Kunti.(2012). Analisis Pengaruh Return On Asset, BOPO dan Suku Bunga Terhadap
Tingkat Bagi Hasil Deposito Mudharabah Pada Bank Umum Syariah. Yogyakarta : Jurnal Ekonomi dan Bisnis. Vol. 11 No.1.

Karim, Adiwarman A, dan Affif, Adi Zakaria.(2005). Islamic Banking Consumer Behaviour in Indonesia: A Qualitative Approach. Jakarta: Karim Business Consulting.

Karim, Adiwarman A, (2016). Bank Islam Analisis Fiqih dan Keuangan.Jakarta : PT. Raja Grafindo Persada.

Latumaerissa, Julius R. (2012). Bank dan Lembaga Kevangan Lain.Jakarta: Salemba Empat.

Muhammad. (2011). Manajemen Bank Syariah.Yogyakarta : Unit Penerbitan dan Percetakan sekolah tinggi ilmu manajemen YKPN.

Nofianti, Nana. dkk. (2015). Analisis Pengaruh ROA, BOPO, Suku Bunga, FDR dan NPF terhadap Tingkat Bagi Hasil Deposito Mudharabah.Banten : Esensi Jurnal Bisnis dan Mnajemen Vol.5.No.1.

(2012). Statistik Perbankan Syariah.Jakarta : Otoritas Jasa Kevangan.

(2013). Statistik Perbankan Syariah.Jakarta : Otoritas Jasa Keuangan.

(2014). Statistik Perbankan Syariah.Jakarta : Otoritas Jasa Keuangan. 
(2015). Statistik

Perbankan Syariah.Jakarta :

Otoritas Jasa Keuangan.

(2016). Statistik

Perbankan Syariah.Jakarta :

Otoritas Jasa Kevangan.

Santoso, Singgih. (2000). Buku Latihan SPSS

: Statistik Parametrik. Jakarta : PT.

Elex Media Komputindo

Solissa, Nuriyah Diyan. (2017). Profit

Equalization Reserve (PER) Sebagai Upaya Mitigasi Risiko Imbal Hasil Perbankan Syariah. Yogyakarta: Az Zarqa', Vol. 9, No. 1, Juni 2017.

Sudarsono, Heri. (2002). Bank dan Lembaga Kevangan Syariah Deskripsi dan Illustrasi.Jakarta : Ekonosia.

Sugiyono. (2015). Metode Penelitian Kuantitatif, Kualitatif dan $R$ \& $D$. Bandung : Alfabeta.

Ulfah, Rizakia. (2011). Pengaruh Makro Ekonomi Terhadap Penetapan Nisbah Bagi Hasil Deposito Mudharabah Perbankan Syariah di Indonesia.Skripsi.Jakarta : Uin Syarif Hidayatullah.

Undang - Undang Republik Indonesia Nomor 21 Tahun 2008 Tentang Perbankan Syariah.

Undang - Undang Republik Indonesia Nomor 10 Tahun 1998 Tentang Perbankan. 